Meta

Journal des traducteurs

Translators' Journal

\title{
The Inception of Translation Culture in Japan
}

\section{Tsutomu Sugimoto}

Volume 33, numéro 1, mars 1988

Traduction et interprétation au Japon

Translation and Interpretation in Japan

URI : https://id.erudit.org/iderudit/004311ar

DOI : https://doi.org/10.7202/004311ar

Aller au sommaire du numéro

Éditeur(s)

Les Presses de l'Université de Montréal

ISSN

0026-0452 (imprimé)

1492-1421 (numérique)

Découvrir la revue

Citer cet article

Sugimoto, T. (1988). The Inception of Translation Culture in Japan. Meta, 33(1),

25-31. https://doi.org/10.7202/004311ar d'utilisation que vous pouvez consulter en ligne.

https://apropos.erudit.org/fr/usagers/politique-dutilisation/ 


\section{THE INCEPTION OF TRANSLATION CULTURE IN JAPAN}

TSUTOMU SUGIMOTO

Waseda University, Tokyo, Japan

Simply speaking, translation is the exchange of one set of clothes for another set of clothes that will cover the same meaning or thought. However, when we think of a translation culture, first we must understand its back-ground and give some thought to the age in which it was born. It was in the age of Rangak $u^{1}$, Dutch learning, in the 18th century that the Japanese first encountered a European language and thought to translate it into Japanese. Before the age of Rangaku, Japan had Christian culture and medical arts, called "Nanban-ryú" ${ }^{2}$. Nanban-ry $\hat{u}$, meaning school of southern barbarians, was the medicine introduced by the Portuguese and Spanish before the Dutch came to Japan. However, the Japanese had awoken to the significance of the Nanban-ry $\hat{u}$, and some of the interpreters studied it and its terminology was accepted into the Dutch medicine, called Kômô-ry $\hat{u}^{3}$ (Kômô refers to the Dutch because of their red hair).

All the Portuguese and Spanish were expelled from Japan in 1638, and after that only the Dutch were allowed to visit and trade at Nagasaki ${ }^{4}$. In spite of the extremely reactionary policy of national isolation, the $B a k u h u^{5}$ government preserved the window of Nagasaki looking out on the rest of world, and wisely kept in contact with both China and Holland. During the 17th century, Kômô-ry $\hat{u}$ was studied by Japanese physicians and some interpreters. We have records showing that lectures by a Dutch doctor were given at Hirado ${ }^{6}$ in 1639 and that Japanese physicians studied under Dutch surgeons from the Dutch East-Indian Company, and there remain five diplomas given to students at Dezima ${ }^{7}$, Nagasaki, during the latter half of the 17th century. Of course, when the Japanese students studied Dutch medicine or surgery, interpreters provided a translation for them, and some interpreters changed their occupation to that of physician as well.

High-ranking officials in the Bakuhu recognized the value of Kômô-ryu and some of them were very interested in Dutch medical books and surgical instruments and asked the opperhoofd or capitão to import them. One of the Daimy $\hat{o}^{8}$ the feudal lords invited a Dutch surgeon to demonstrate the dissection of pigs in 1658. In the Dagregister of opperhoofd we can find lots of information about the birth of the scientific spirit or curiosity among the Japanese.

Generally speaking, however, it seems that the Dutch influence on Japanese medicine was not very strong or significant in the 17 th century. It is extremely probable that the weakness of the interpreters in the Dutch language was due primarily to a lack of proper tools for their work, such as grammars and dictionaries. However, we have two remarkable translations of Dutch anatomical books done by interpreters. One is entitled "Hôi Geka Sôden"9 ( Red-haired Barbarian Surgery Handed Down) by Narabayasi Tinzan ${ }^{10}$, a member of a Nagasaki family of interpreters who studied Dutch surgery under doctors from Holland. The original book was the "Chirurgie ende Opera van 0 alle de Werken, 1649" by Ambroise Paré, who was famous as the "Father of French Surgery", and who appears as a noted physician in "Sur Catherine de Médicis" by Honoré de Balzac. The other translation is the "Oranda Keiraku no Zu"11 (Atlas of the 
Dutch Acupuncture Points) by Motoki Ryôi (Syôdaŷ̂. $)^{12}$, a member of another Nagasaki interpreter family. He was originally an interpreter but, in attending the Dutch doctors, he learnt about Dutch surgery and medicine. Among the Dutch doctors were excellent surgeons, like Casper Schamberger, W. ten Rijne and E. Kaempfer.

Ryôi's translation has come down to us in written copies. Among them there is one entitled "Kômô Dôningyố"13 (Red Haired Copper-Doll). This title is interesting from the viewpoint of Ryôl's knowledge of anatomy, because "Dôningyô" suggests the copper model of the human body used in traditional Chinese folk medicine. During the $E d o^{14}$ period (from the 17th century to the 19th century), these copper models were imported to Japan from China and some Japanese artisans reproduced them (we can see them in museums today). It seems likely that $R y \hat{o} i$ made an analogy between the practical utility of the Dutch anatomical charts and such Chinese models. Moreover, the "Oranda Keiraku no Zu" was retitled the "Oranda Naigai Bungô Zu" ${ }^{15}$ (Charts of the inside and outside of Hollander) afterwards and was published in 1772. The original text is entitled "Joh. Remelini, L.A.M. \& M.D. ; Pinax Microcosmographicus, etc. Ontleeding des Menschelyke Lichaems, etc., $2^{\text {nd }}$ ed., 1667". Ryôi, first of all, had to confront the problems of translating medical terms into Japanese. He translated the term "blind darm", or "caecum" in Latin, into "mômokutyô"16 in japanese and he also translated "twalf vingerlinfen darm" into by "Yubi Zyûni Haba no Tyôo"17", and "het vliesken van de trommel" by "Taiko no otosuru Usumaku"18. Although the word "otosuru"19 in Japanese does not correspond with any part of the Dutch term trommel-vliesken, Ryô $i$ added it in a free translation in order to be easily understood. ThusRyôi sometimes translated word for word and sometimes used phrases for words. Such a special term as "Zenuw" was translated by "Zuikin"20 or "Kin"21, terms which had been used in Chinese medicine. From a terminological point of view, Ryô $i$ combined Dutch medicine with Chinese, as in the case of "zenuw", but some interpreters who specialized in Dutch medicine translated the term "zenuw" as "Nerubo"22, from the Portuguese word "Nervo" used in the

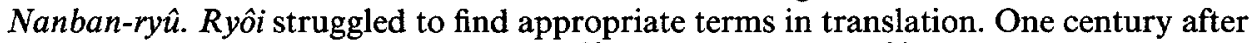
Ryô $\imath$ 's work, we have the "Kaitai Sinsyo"23 by Sugita Genpaku ${ }^{24}$, in which terms such as "Môtyô, Zyûnisityô, Komaku and Sinkey", etc., were used, retranslated from Ryôi, terms which still live on in the medical world in Japan. And interpreters specializing in Dutch medicine compiled glossaries of medical terms in Japanese, Portuguese, Dutch and Latin. People who studied Dutch medicine at Nagasaki and who came from all over Japan, copied from Ryôi's work or compiled glossaries by themselves, and when their work was approved, they took these terms to their own areas.

At any rate, I may say that "Rangaku" began in the 18 th century. The motivation to study Dutch medicine and surgery was stimulated by a new positive movement of the old school of traditional Chinese medicine. The first dissection of a human corpse was performed by Yamawaki Tôyô, physician of Chinese medicine to the emperor, at Kyôto in 1754. He published his records of the dissection in a book entitled "Zô Si" (Description of Organs), in which there are several rather crude anatomical charts. This is the true beginning of experimental medicine, some fourteen years before the publication of the "Kaitay Sinsyo" (New Book for Dissection) in 1774. The Kaitai Sinsyo was translated by Sugita Genpaku and Maeno Ranka ${ }^{25}$. Genpaku was greatly excited by Yamawaki Tôyô's dissection and anxious to perform a dissection himself. In 1771 he and his friends attended the dissection of the corpse of an old woman in Edo. In keeping with the experimental spirit of the times, Genpaku, a student of Dutch surgery for some time, compared the anatomical arrangement of the corpse with the charts of the Dutch anatomy book by $\mathbf{J}$. Kulmus's and he was amazed and impressed by the accuracy of the 
western work in contrast to the petrified Chinese teachings. As a result, he decided to translate Kulmus's book into Japanese.

The Kaitai Sinsyo was actually translated by Maeno Ranka, who was one of Genpaku's collaborators and played the leading part in the translation. Ranka was an official physician and a student of an old school of Chinese medicine called the Kohôka ${ }^{26}$ along with Yamawaki Tôyô. However, he was ordered to study Dutch medicine and the Dutch language under the tutelage of interpreters at Nagasaki by his feudal lord who held very progressive ideas. Ranka was the first outstanding scholar of Dutch learning, who symbolized the encyclopedic activities of the Japanese physician and was well versed in the various sciences. He wrote some books on the Dutch language and proposed a way to translate it. He himself termed his method Rankatei-Yakubunsiki ${ }^{27}$. He based it on the Kanbun-Kundokuhô ${ }^{28}$ or the method of reading Chinese classical scripts in use since fairly ancient times in Japan. I would say the Rankatei-Yakubunsiki is a unique method of translation created by the Japanese. Perhaps it was suggested to Ranka by interpreters at Nagasaki.

Ranka's method of translation, as mentioned above, owes much to the method of reading Chinese.

As is well known, the Japanese have inherited much of their civilization from China. Some knowledge of writing was probably introduced into Japan from China at a relatively early date. For the most part, educated men in old times disdained the use of their own tongue for any serious literary purpose and continued to write histories, essays and official documents in Chinese. Japanese scholars, reading the Chinese symbols, would, no doubt, have been guided first only by the sense of the Chinese symbols learned from their instructors. Since the Chinese logograph can convey to the eye any meaning conventionally assigned to it, irrespective of the sound by which it may be known, it would have been possible for Japanese scholars to read a passage of Chinese without knowing how it was pronounced in Chin ing the Chinese symbols into Japanese words. Japanese students of Chinese could have understood the meaning of characters without actually translating them into words, either Chinese or Japanese. The Japanese would have retained in their minds the meanings assigned to a large number of Chinese characters through a great effort of visual memory. In that way it became customary to read Chinese texts aloud. This habit continues to this day. As we know, Chinese and Japanese belong to completely different language families. Chinese is monosyllabic and uninflected and the function of words is determined by position, while Japanese is polysyllabic and inflected. The order of words in Chinese is, in almost every respect, the opposite of Japanese. The whole grammatical structure is different. The pronunciation in reading the Chinese classics did not matter to the Japanese students. The important things was to appreciate the meaning and convey it to others. It is clear that for practical purposes some arrangements had to be made to facilitate the reading of Chinese texts by Japanese scholars who were not familiar with Chinese pronunciation and Chinese grammar, so devices for reading and interpreting passages from Chinese classics were invented. This system is termed the KanbunKundokuhô (Kanbun 29 means Chinese sentences).

There were important considerations which guided the Japanese in building up a system by which they could adapt Chinese characters to their own needs, and these led to results which must surely be unique in the history of language and culture. Japanese scholars also learnt a system of phonetic translation of Chinese characters from Buddhist Scriptures. What they needed was not to exchange the symbols for the words for which they stood, but rather to rearrange the symbols in accordance with Japanese syntax. The separate ideas conveyed by Chinese characters were clear enough to Japanese 
who had learnt them by rote, and the Japanese used the Chinese characters in the word order natural to Japanese and supplied the inflections, particles and so on, which are necessary in Japanese to show the relations between words. The inflections and particles were given in $K a n a^{30}$, or dots in some cases, which were placed on the lower right of the appropriate character. In order to give indications of Japanese word order, Japanese scholars combined them with a system of markings (equivalent to the numerals and characters in the following examples) to show the order and grouping of the characters. Figures or marks are placed on the lower left of the Chinese character to which they apply. The mark " $\nu$ " placed on the lower left of a Chinese character indicates that this character and the following ones are to be read in reverse of the Chinese order. This mark may be used in conjunction with other figures or markings. Now, as they say, the proof of the pudding is in the eating, so I would like to offer some examples from the Chinese classics in the box below.

(2)

\begin{tabular}{ll} 
父 & $\mathrm{HU}$ \\
子 & $\mathrm{SI}$ \\
不 & $\mathrm{zu}$ \\
\hline 相 & $\mathrm{ai}$ \\
見 & $\mathrm{mi}$ \\
兄 & $\mathrm{KEI}$ \\
弟 & $\mathrm{TEI}$ \\
妻 & $\mathrm{SAI}$ \\
子. & SI \\
離 & RI \\
散 & SANsu
\end{tabular}

Father and sons do not see one another; elder brothers and younger brothers, wives and children are scattered.
(1)

$$
\begin{aligned}
& \text { 民 tami } \\
& \text { 之 no } \\
& \text { 掃 kisuru } \\
& \text { E. ZIN } \\
& \text { 也 ya } \\
& \text { 猛首 nawo, gotosi } \\
& \text { 水 } \mathrm{mizu} \\
& \text { 之 no } \\
& \text { 亮 tuku ga } \\
& F_{\underline{\underline{\underline{t}}}} \text { hikukini }
\end{aligned}
$$

The turning of the people to benevolence is just like the way water moves downwards.

As the Rangakusya ${ }^{31}$ pointed out, the syntactical pattern of Dutch, that is, the structure of $\mathbf{S}$. + P. + O. is identical to that of Chinese as the above examples show, while the structure of Japanese is S. + O. + P. Next, I would like to give examples quoted from the books written by Ranka and his disciples.

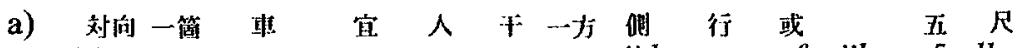

Voor een wagen, moet men aan een zijde gaan, of wijken, 5 ellen.

$=$ For a wagon, men must go or give way 5 feet by the side.

b) (發諱)ソ 今日 好キ天荣

Het is vandag mooi weer. = It is today good weather.

c) ワレハ為你 媛

$I k$ ben $u$ dienaar. $=$ I am your servant.

d) 予 有千把利斯在リシニト

$I k$ hebbe te parijs geweest. = I had lived in Paris. 
When the Rangakusya read a medical text, they used to follow the same pattern as in the examples just quoted :

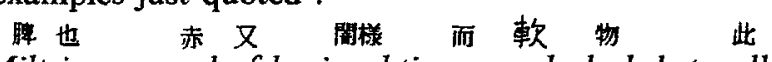

$O$ De Milt is een rood of bruinachtig en week deel, het welk

自 易 為 $\ni$ 分解

zich gemakkely laat van een scheiden.

$=$ The spleen is a red or brown and weak part, that itself gets easily a separation.

Furthermore in learning Dutch grammar, they would be provided with Ranka's method :

人 得 実名詞於二ッ，大種㓋

* Men kan de zelfstandige naamwoorden in twee hoofdsoorten

区别 於 種多， 国詞部分 即 文章部分

onderscheiden (over de onderscheidene Taal of Rededeelen)

- Men can classify the substantives into two classifications.

We can trace Ranka's method up to the eighteen eighties : students used to follow Ranka's method in learning English grammar in the Meizi ${ }^{32}$ period.

On the other hand, from the point of view of cultural borrowing, we have to consider the translation of words. In the preface of the Kaitai Sinsyo, three classifications of translation are given. The first one is so-called translation in the narrow sense : it is a kind of intimate borrowing ; the second is broad translation; the third is transliteration. Genpaku wrote in his essay, "This method was suggested by Buddhist Scriptures in the Chinese language, which were translated from ancient Hindi in the third century B.C.".

The first type of translation was completely different from the type presentely used : it consisted in substituting a term from the Chinese language, which was equivalent to the traditional medical term in the Dutch language, for instance, Sibo ${ }^{33}$ for vet, Ketueki ${ }^{34}$ for bloed and Nŷuzy $\hat{u}^{35}$ for melk in the Dutch language. In of the second type of translation, a large number of new terms were produced, for instance, Môty $\hat{o}^{36}$ for blind darm, Sinkei ${ }^{37}$ for zenuw and Nankotu ${ }^{38}$ for kraakbeen. In the third type a lot of words were produced, such as Kiriiru ${ }^{39}$ for klier, Bando ${ }^{40}$ for band and Geiru ${ }^{41}$ for geil.

In the history of Japanese translation, Udagawa Gensin ${ }^{42}$ (1769-1834), the second disciple of Maeno Ranka, is the greatest translator of the Edo period. He produced important new coined words such as Zintai ${ }^{43}$ for band, Sui ${ }^{44}$ for gor groot klier (pancreas), Titu ${ }^{45}$ for schede (Vagina) and others used in the modern medical world, and he compiled the first glossary of medical terms in Dutch, Latin and Japanese. Before this, a small glossary had been compiled by Ôtuki Gentaku ${ }^{46}$, disciple of Maeno Ranka, in the first half of the 19th century. It was a supplement to his translation "Tyôtei Kaitai Sinsyo" $^{\text {"47 }}$ which was another and somewhat expanded edition of the Kaitai Sinsyo. For reference, let me pick out two terms from it.

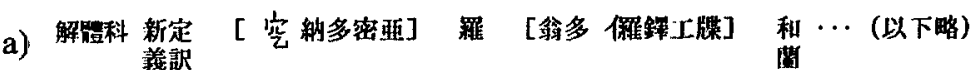

* Kaitai (a broad translation, new term), Anatomia (Latin), Ontleed-kunde (Dutch) ... (the rest is omitted) 


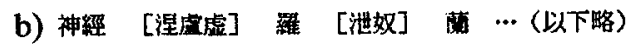

*Sinkei, Nervi (Latin), Zenuw (Dutch) ... (the rest is omitted)

In this glossary, Gentaku included two kinds of language : one in Chinese characters, and the other in Japanese letters called Kana, converting Latin and Dutch medical terms to Japanese equivalents. He never put Roman letters in his glossary. However, in the next century, the Rangakusya generally presented Kana letters in transliteration.

In general, the Rangakusya's method of translation was founded on a recognition of language as code (H.E. Palmer's term), and they put their knowledge to practical use ... to translate messages into code.

In the cultural borrowing of the Edo period, the Rangakusya devised a triple tier translation system in Japanese, Chinese and Dutch, and they succeeded in transplanting European science or culture into Japan through the Dutch language which the Hollanders had brought to Japan. Good examples of this are found in Udagawa Gensin's work, the "Seisetu Ihan Teikô Syakugi"48 (Outline of Splanchnology), in which there are a number of appropriated Japanese equivalents, for instance, Sen ${ }^{49}$ for Klier, Zintai ${ }^{50}$ for Band and Nyûbi ${ }^{51}$ for Geil. These terms are still available today.

In Ranka's method of translation, Chinese characters provided the skeleton of a statement, which was covered with a cutis of Dutch language, and clothed in an elaborate grammatical robe of Japanese texture. The inevitable complexities in such a mixed system of reading and writing were increased by other factors. The Japanese language was poor in technical terms, and it was therefore essential to preserve a large number of Chinese words which could not be satisfactorily rendered in Japanese. Consequently thousands of Chinese words were gradually incorporated into the Japanese language, and most of the characters came to stand not only for the Japanese version of the original Chinese words but also for the corresponding Japanese words. In the Edo period, many technical and scientific terms were borrowed from Chinese or coined in Japanese by joining two or more Chinese characters. Needless to say, the Dutch language performed a great role in bringing the clothing of modernization to the civilization of $\mathrm{Ja}$ pan.

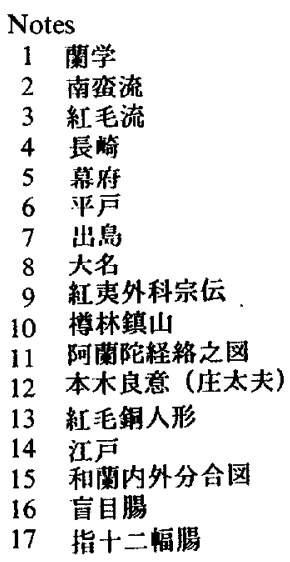




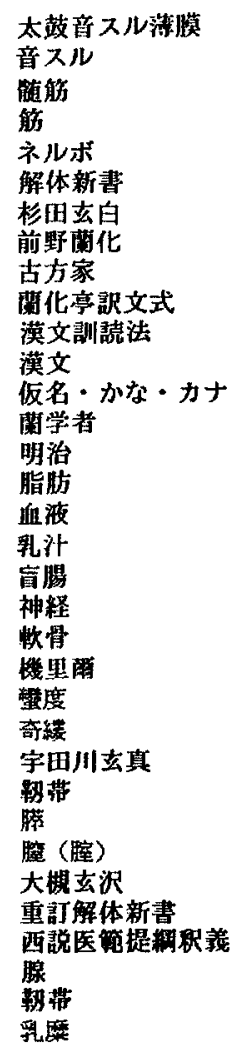

\section{REFERENCES}

SUGIMOTO, T. (1976) : Dutch Linguistics, Its Formations, Growth and Development, Tokyo, Waseda University Press.

BOXER, C.R. (1968) : Jan Compagnie in Japan 1600-1817, Tokyo, London, Oxford University Press. GOODMAN, G.K. (1967) : The Dutch Impact on Japan (1640-1853), Leiden, Monographies to T'oung Pao, vol. $\vee$.

MORI, K. (1942) : Die Anfänge der Holland-Kunde, Translation, Tokyo, Monumenta Nipponical, vol. v. 